\title{
The impact of COVID-19 on pharmacy education: Perspectives of Nigerian undergraduate pharmacy students
}

\author{
Roland Nnaemeka Okoro (D), Deborah Oyine Aluh² (D), Aminu Ahmed Biambo ${ }^{3}$, Erick Wesley Hedima ${ }^{4}$, \\ Kennedy Emeka Oluigbo ${ }^{5}$ \\ ${ }^{1}$ Department of Clinical Pharmacy and Pharmacy Administration, Faculty of Pharmacy, University of Maiduguri, Nigeria \\ 2Department of Clinical Pharmacy and Pharmacy Management, Faculty of Pharmaceutical Sciences, University of Nigeria, Nigeria \\ ${ }^{3}$ Department of Clinical Pharmacy and Pharmacy Practice, Faculty of Pharmaceutical Sciences, Usmanu Danfodiyo University, Nigeria \\ ${ }^{4}$ Department of Clinical Pharmacy and Pharmacy Practice, Faculty of Pharmaceutical Sciences, Gombe State University, Nigeria \\ ${ }^{5}$ Department of Clinical Pharmacy and Biopharmaceutics, Faculty of Pharmaceutical Sciences, Enugu State University of Technology, \\ Nigeria
}

\author{
Keywords \\ COVID-19 \\ Nigeria \\ Online Learning \\ Pharmacy Education \\ Pharmacy Students \\ Undergraduate
}

\section{Correspondence}

Roland Nnaemeka Okoro

Department of Clinical Pharmacy

and Pharmacy Administration

Faculty of Pharmacy

University of Maiduguri

Borno State

Nigeria

orolandn@gmail.com

\begin{abstract}
Context: Globally, every school and college of pharmacy is challenged to respond to the impact of COVID-19 on pharmacy education and must find ways to continue to communicate with colleagues and educate their students. Aims: To describe the impact of COVID-19 on undergraduate pharmacy students' education and learning in Nigeria. Methods: This was a cross-sectional study with an online questionnaire. A validated questionnaire was used to collect data from the students. Associations between learning and respondents' characteristics were determined with either chi-square test or fisher's exact test at $p<0.05$. Results: Most of the students $(91.0 \%, n=343 / 377)$ were not taught during COVID-19 school closures in Nigeria. The school closures had a significant effect on the academic lives of most students $(99.2 \%, p<0.05)$. Extension of graduation year was the highest $(24.2 \%)$ academic impact. High cost of internet data $(28.6 \%)$ was the most common challenge with online learning among the students. A marked proportion (70.9\%, $(p<0.05)$ of the students preferred a combination of online and face-to-face learning methods after the pandemic. Conclusions: COVID-19 has impacted pharmacy education in Nigeria due to the discontinuity of learning, a lack of effective online learning, and an extension of students' expected year of graduation. A combination of online and face-to-face learning methods was perceived to be better after the pandemic. This finding highlights the need for Nigerian pharmacy educators to tap into the opportunities presented by the pandemic to improve pharmacy education and ultimately pharmacy practice in the country.
\end{abstract}

\section{Introduction}

Globally, a highly infectious disease caused by a new virus (Coronavirus) emerged in Wuhan City, China in December 2019 (WHO, 2020). As of 12th October 2020, there were $37,544,120$ confirmed cases and 1,077,082 deaths in 188 countries/regions worldwide (Johns Hopkins University, 2020); a number that has continued to increase. Of these numbers, Nigeria contributed 60,266 confirmed cases, and 1,115 deaths (Nigeria Centre for Disease Control, 2020). 
As of 6th April, 2020, over one million enrolled learners at all levels of learning worldwide have been affected by this pandemic (UNESCO, 2020a). Therefore, teaching and learning have been impacted in the most direct way, primarily due to schools being closed and the absence of options for face-to-face interactions for an extended period in most countries, especially in low-and mediumincome countries (LMICs).

The impact of COVID-19 on higher education has challenged every school and college of pharmacy worldwide to devise ways to sustain connectivity and communication with colleagues and students (Sorensen, Lin, \& Allen, 2020). In view of this, after understanding that the COVID-19 pandemic and mitigating measures would last for months, most developed countries swiftly moved to online teaching and learning at the tertiary level (Stone \& Pate, 2020). Regrettably, numerous higher education institutions in most developing countries, including Nigeria, are not well prepared to implement online teaching and learning (Toquero, 2020).

From the Nigerian perspective, in an effort to contain the spread of the virus, the National Universities Commission (NUC) ordered the indefinite closure of universities nationwide effective from 23rd March 2020 (Azeezat, 2020). With this sudden and unprecedented development, the only academic continuity option available for exploration for colleges and universities was remote teaching and learning.

Most pharmacy schools in Nigeria offer a five-year Bachelor of Pharmacy (B.Pharm.) degree programme (Okoro \& Biambo, 2020). Recently, a six-year Doctor of Pharmacy (Pharm.D.) programme was approved by the apex education regulatory agency (National Universities Commission) in Nigeria (Pharmanews, 2016). The implication of this approval is that Nigerian universities offering pharmacy programmes are expected to gradually phase out the B.Pharm. programme and replace it with the Pharm.D. programme. These universities produce an estimated average of 1,200 new pharmacists per year (Ekpenyong et al., 2018).

Currently, there are 24 pharmacy schools in Nigeria (22 public pharmacy schools [ 16 federal and 6 state], and two private pharmacy schools) (Famodun, 2019). The benchmark for pharmacy education in Nigeria encourages face-to-face didactic lectures, tutorials, case studies, presentations, and practical sessions as the methods of imparting knowledge to pharmacy students (Pharmacists Council of Nigeria, 2020). Though some universities in the country, especially privately and some state-owned institutions have embraced online learning (Okocha,
2020), the fact is that most universities in the country lack basic technological infrastructure and innovations to thrive amidst the pandemic. This is largely due to poor digital infrastructure and access to teaching resources, low manpower development especially academic personnel, and poor quality research which constitute persistent constraints to the delivery of quality higher education, including pharmacy education in developing nations (Anderson, et al., 2014). Therefore, the additional impact of COVID-19 pandemic on pharmacy education in the country is grave because most pharmacy students were either in the process of commencing experiential learning programmes or undergoing terminal assessments.

The COVID-19 pandemic, without a doubt, constitutes a burden on the Nigerian students, including pharmacy students, in addition to the myriad problems already confronting them at university (Ige, 2014). Therefore, the objectives of the study were to assess the current learning status of undergraduate pharmacy students in Nigeria; the extent to which COVID-19 pandemic schools' closure impacted their academic lives; the challenges of online learning among them; and to explore their perspectives of a 'new normal' post-COVID-19 teaching and learning strategy for undergraduate pharmacy students in the country.

\section{Methods}

\section{Study design and settings}

This was a descriptive cross-sectional online national survey among undergraduate pharmacy students in all 24 pharmacy schools in Nigeria.

\section{Sample size calculation}

The minimum sample size required for the study was calculated using an online Raosoft sample size calculator. In calculating the sample size, the approximate population of Nigerian undergraduate pharmacy students in $2019 / 2020$ academic year $(15,000), 5.0 \%$ margin of error, and a $95.0 \%$ confidence interval were used. Thus, the recommended sample size for the study was 375 . In anticipation of $20.0 \%$ non-response, sample size was increased to 450 .

\section{Participants}

The undergraduate pharmacy students in Nigeria constituted the study population. The inclusion criteria were: being an undergraduate pharmacy student in the 2019/2020 academic year, with internet access, active 
WhatsApp account, and willingness to participate in the study. The exclusion criteria were: being withdrawn from pharmacy programme, post-graduate pharmacy students, non-pharmacy students, inactive WhatApp account, lack of internet access, and unwillingness to participate in the study. The participants were conveniently selected from all the pharmacy schools in Nigeria using WhatsApp.

\section{Study instrument}

The instrument used was a validated questionnaire that contained two sections. The first section had questions on the demographic and school-related characteristics. The second section contained 12 questions on students' perspectives of pharmacy education amidst the COVID-19 pandemic. Of the 12 questions, four were dichotomous ('Yes' and 'No'), and six were multiple-choice, while the remaining two-items were rated on a 5-point Likert scales, ranging from 'Strongly agree' to 'Strongly disagree'. The research objectives guided the development of the instrument. The questionnaire items were generated from a review of relevant literature and the contents of International Pharmaceutical Federation (FIP) impact of COVID-19 on pharmacy education, as well as remote and online education during COVID-19 webinars of 28th May and 3rd June 2020, respectively (FIP, 2020).

The 12-items generated were subjected to content validity by three experts in pharmacy education, while items' face validity was conducted among ten pharmacy students who were excluded from the main study. Ambiguous words or items with high non-responses were reworded to ensure clarity. Thereafter, a pilot study was conducted using 20 pharmacy students who were also excluded from the main study. The questionnaire had an adequate average Cronbach's alpha of 0.643.

\section{Ethical considerations}

Participation was voluntary and informed consent was obtained from all the study participants. Before completing the questionnaire, a mandatory informed consent field must be checked by the participants to gain access to the study questions. Participants were assured of anonymous data collection. Ethical approval for the study was granted by the Research Review Board of the Faculty of Pharmacy, University of Maiduguri, Nigeria.

\section{Data collection}

Data were collected online using Google Forms over a three-week period (20th July to 9th August 2020) via the WhatsApp platform. The information collected included respondents' demographic and school characteristics such as age, gender, location of the university, ownership of the university, and COVID-19 academic perspectives.

\section{Statistical analysis}

For statistical analysis, the 5-point Likert scales were dichotomised ('Disagree' [neutral, disagree, and strongly disagree], and Agree [agree, and strongly agree]). Participants' demographic characteristics and responses were summarised using descriptive statistics (frequency, percentage, mean, and standard deviation). Chi-square test or Fisher's exact test was used to investigate relationships between learning and respondents' characteristics. Probability values $<0.05$ were considered statistically significant.

\section{Results}

Of the 450 students who were invited to participate in the study, 377 completed the questionnaire giving a response rate of $83.8 \%$. The mean age of the respondents was $22.1 \pm 3.0$ years. A majority $(90.7 \%, n=342 / 377)$ were between the age range of 25 years and less; $53.1 \%$ were females. Most of them were from public universities (92.8\%, $n=350 / 377)$. The detailed respondents' demographic information is presented in Table $\mathrm{I}$.

Table I: Demographic characteristics of the respondents ( $N=377)$

\begin{tabular}{lc}
\hline Variable & $\mathbf{n}(\%)$ \\
\hline Age (years) & $342(90.7)$ \\
$\leq 25$ & $35(9.3)$ \\
$>25$ & \\
\hline Gender & $200(53.1)$ \\
Female & $177(46.9)$ \\
Male & $27(7.2)$ \\
\hline School ownership & $350(92.8)$ \\
Private & $189(50.1)$ \\
Public & $188(49.9)$ \\
\hline School location & \\
North &
\end{tabular}

The most common personal learning effort during COVID-19 school closure reported by the respondents was studying at home (32.7\%, $n=179 / 547)$. Nearly all $(99.2 \%$, $n=374 / 377$ ) respondents reported that the COVID-19 
school closure had impacted their academic lives with a significant difference. Extension of the expected year of graduation was ranked-highest $(24.2 \%, n=296 / 1221)$ among the academic impacts of COVID-19 school closures by the respondents (Table II).

Table II: Respondents reported personal learning efforts during COVID-19 schools closure and the impacts of the pandemic on their academic lives

\begin{tabular}{|c|c|}
\hline Variable & n (\%) \\
\hline \multicolumn{2}{|c|}{ Students personal learning efforts during COVID-19 schools closuret } \\
\hline Studying at home & $179(32.7)$ \\
\hline I have not been studying since schools closure & $132(24.1)$ \\
\hline Online discussion with fellow pharmacy students & $96(17.6)$ \\
\hline Online courses participation & $82(15.0)$ \\
\hline Online conferences/webinars participation & $58(10.6)$ \\
\hline \multicolumn{2}{|c|}{ Has COVID-19 schools closure impacted your academic life?* } \\
\hline No & $3(0.8)$ \\
\hline Yes & $374(99.2)$ \\
\hline \multicolumn{2}{|l|}{ Specific impactst } \\
\hline My stay in pharmacy school has been extended & $296(24.2)$ \\
\hline $\begin{array}{l}\text { I have started forgetting what I learned before th } \\
\text { schools closure }\end{array}$ & $266(21.8)$ \\
\hline My examinations were suspended & $209(17.1)$ \\
\hline $\begin{array}{l}\text { I have not been able to learn new things again wi } \\
\text { my pharmacy programme }\end{array}$ & $185(15.2)$ \\
\hline Extra financial burden to me & $161(13.2)$ \\
\hline My project work has been suspended & $104(8.5)$ \\
\hline
\end{tabular}

*Fisher exact test significant at $p<0.05$; + Multiple responses were allowed; \#Percentage was based on the total number of respondents on each item

Table III: Association between teaching during COVID-19 schools closure and respondents' school characteristics ( $N=377)$

\begin{tabular}{|c|c|c|c|c|c|}
\hline \multirow[t]{2}{*}{ Variable } & \multirow[b]{2}{*}{$\begin{array}{l}\text { Total } \\
\text { N (\%) }\end{array}$} & \multicolumn{2}{|c|}{$\begin{array}{l}\text { Is your school teaching } \\
\text { during COVID-19 schools } \\
\text { closure? }\end{array}$} & \multirow[b]{2}{*}{$\chi^{2}$} & \multirow[t]{2}{*}{$p$-value } \\
\hline & & $\begin{array}{c}\text { No } \\
n \text { (\%) }\end{array}$ & $\begin{array}{c}\text { Yes } \\
\text { n (\%) }\end{array}$ & & \\
\hline \multicolumn{6}{|c|}{ School ownership } \\
\hline Private & $27(7.2)$ & $6(22.2)$ & $21(77.8)$ & 185.640 & $<0.001^{*}$ \\
\hline Public & 350 (92.8) & $337(96.3)$ & $13(3.7)$ & & \\
\hline \multicolumn{6}{|c|}{ School location } \\
\hline North & $189(50.1)$ & $181(95.8)$ & $8(4.2)$ & 10.579 & $0.001 *$ \\
\hline South & 188 (49.9) & $162(86.2)$ & $26(13.8)$ & & \\
\hline
\end{tabular}

${ }^{*}$ Chi-square test $\left(\chi^{2}\right)$ significant at $p<0.05$

There was no continued learning for a significant majority (91.0\%) of undergraduate pharmacy students during COVID-19 school closure in Nigeria. Similarly, significant proportions ( $77.8 \%, n=21 / 27$ and $13.8 \%, n=26 / 188$ ) of the respondents from private universities and universities located in southern Nigeria reported continued learning during COVID-19 school closure, respectively $(p<0.05)$

Table IV: Respondents reported online learning methods, challenges and perspectives on way forward for pharmacy education in Nigeria

\begin{tabular}{|c|c|}
\hline Variable & $\mathrm{n}(\%)^{\#}$ \\
\hline \multicolumn{2}{|l|}{ Is your school teaching online? } \\
\hline No & $4(11.8)$ \\
\hline Yes & $30(88.2)$ \\
\hline \multicolumn{2}{|l|}{ Online teaching platform ${ }^{\dagger}$} \\
\hline Cloud meeting apps & $28(59.6)$ \\
\hline Messaging apps & $11(23.4)$ \\
\hline Students e-learning portal & $8(17.0)$ \\
\hline \multicolumn{2}{|l|}{ Is the online teaching real time? } \\
\hline No & $4(13.3)$ \\
\hline Yes & $26(86.7)$ \\
\hline \multicolumn{2}{|l|}{ Non real time methodt } \\
\hline Shared lecture video links & $4(57.1)$ \\
\hline Topics sent through text messages & $3(42.9)$ \\
\hline \multicolumn{2}{|l|}{ Non real time mode of delivery ${ }^{\dagger}$} \\
\hline Document-based reading materials only sent through email & $4(22.2)$ \\
\hline Students e-learning portal & $4(22.2)$ \\
\hline $\begin{array}{l}\text { Document-based reading materials only sent through } \\
\text { whatsApp or telegram }\end{array}$ & $4(222)$ \\
\hline Lecture videos only sent through email & $3(16.7)$ \\
\hline $\begin{array}{l}\text { Lecture videos only sent through whatsApp or telegram or } \\
\text { you tube }\end{array}$ & $3(16.7)$ \\
\hline \multicolumn{2}{|l|}{ Online learning challengest } \\
\hline High cost of internet data & $30(28.6)$ \\
\hline Poor internet connectivity/coverage & $26(24.8)$ \\
\hline Poor ICT/digital skills of my lecturers & $19(18.1)$ \\
\hline Erratic/epileptic power supply & $13(12.4)$ \\
\hline High cost of personal computer and smart phone & $13(12.4)$ \\
\hline My poor ICT/digital skills & $4(3.8)$ \\
\hline
\end{tabular}

Online learning only should be a new normal for pharmacy education in Nigeria*

$\begin{array}{ll}\text { Disagree } & 216(57.3) \\ \text { Agree } & 161(42.7)\end{array}$

A combination of online $\&$ face-to-face learning should be a new normal for pharmacy education in Nigeria*

Disagree $110(29.2)$

Agree

$267(70.8)$

${ }^{*}$ Chi-square test $\left(\chi^{2}\right)$ significant at $p<0.05 ;+$ Multiple responses were allowed; "Percentage was based on the total number of respondents on each item; ICT= Information and Communication Technology

Of the students who reported continued learning despite COVID-19 school closure, $88.2 \%$ of them were engaged in online learning by their school. Cloud meeting apps were the most utilised online learning platform (59.6\%, $\mathrm{n}=28 / 47$ ) among these students. Those who were 
engaged in online learning by their schools reported high cost of internet data $(28.6 \%, n=30 / 105)$ as their most common challenge with online learning. A significant (57.3\%, $\mathrm{n}=216 / 377, \chi 2=8.024, p=0.005$ ) proportion of the students disagreed that online learning alone could serve as a better post-COVID-19 pandemic learning method. Also a considerable proportion (70.9\%, $n=267 / 377$, $\chi 2=65.382, p<0.001)$ of the study population valued a combination of online and face-to-face learning methods as a new normal post-COVID-19 teaching and learning strategy for pharmacy students in Nigeria as shown in Table IV.

\section{Discussion}

Despite the high number of respondents who reported that they studied on their own at home, a considerable proportion reported that they had not been able to study as much as necessary since the school shutdown due to COVID-19 pandemic. This highlights the need for online learning to ensure continuity of learning among pharmacy students even after this pandemic. Similarly, a significant proportion of the study participants reported that COVID-19 school closure had impacted their academic lives. The most common impact reported by the respondents was the extension of their expected year of graduation which comes with a lot of other implications. Education funding is critical in developing nations where scholarships are difficult to secure for most students and student loans are also non-existent or inefficient in these countries (Kossey, \& Ishengoma, 2017; Okoro, Muslim, \& Biambo, 2020). In addition, the temporary closure of schools and suspension of classroom activities has left undergraduate pharmacy students in a completely new situation without a clear idea of how long the impact will last, and feeling its immediate effect on their daily life, cost of living and other financial burdens and, naturally, on the continuation of their studies.

A significant proportion of the respondents from private universities compared to those from public universities reported continued learning from their institutions despite the schools' physical closure. Better funding of education by the private sector could explain this finding (Akpotu, \& Akpochafo, 2009). Additionally, private universities' ability to ensure educational continuity for their students amid the current crisis may be due to their emphasis on the integration of technology in learning (Okocha, 2020). They are better equipped with online learning capability that allows them to adapt to and provide uninterrupted services to their students in a variety of situations, such as the ongoing COVID-19 crisis
(Okocha, 2020). This highlights the need for public universities to invest in ICT. Using technology is now essential for academics to teach students remotely in view of the large proportion of the respondents in the current study who were unable to study or learn on their own since the school shutdown. Regrettably, poor funding of education by the Nigerian government with an attendant consequence of little or no special fund allocation for the latest technologies and ICT initiatives in the public education sector has resulted in a lack of basic infrastructure to support online teaching and learning in the public higher education institutions. For example, the Nigerian government allocated only $6.7 \%$ of the 2020 budget to the education ministry (Amoo, 2019) far below the 15 - 20\% recommendation by the United Nations Educational, Scientific and Cultural Organisation (UNESCO) (UNESCO, 2015).

Nevertheless, a few public universities that offer online learning are owned by some state governments who have declared a state of emergency in their education sector with improved funding. Similar to the Nigerian scenario, in Pakistan, it was reported that only a few higher institutions were able to introduce effective online classes during the initial months of COVID-19 due to the limited resources of the institutions (Adnan \& Anwar, 2020). Conversely, in the developed countries, for example, the United States of America, despite pharmacy students being affected by and experiencing COVID-19 in unique ways; most colleges of pharmacy amidst COVID-19 lockdown swiftly switched to online teaching and learning within a reasonable short period of time (Stone \& Pate, 2020). Pharmacy students from some of these schools were able to complete their practice experiences in an online format (Stone \& Pate, 2020).

The current study also revealed that a significant number of pharmacy students from pharmacy schools in southern Nigeria had continued learning during this pandemic compared to those from the northern part of the country. The presence of the only two private pharmacy schools in the south compared to none in the north may have been a contributing factor for this finding. However, of the students that had continued learning despite COVID-19 school closure, a majority reported that their schools offered online teaching to them via cloud meeting apps such as Zoom. It has been reported that videoconferencing applications such as Zoom and Webmax are throwing universities a lifeline (Kandri, 2020).

The most frequently encountered challenges with online learning among the respondents were the high cost of internet data and poor connectivity/coverage. This is comparable to the poor signal availability/strength and 
high cost of internet services reported among Pakistani higher education students (Adnan \& Anwar, 2020), and network congestion reported among Chinese students (Chen et al., 2020). According to the UNESCO global survey findings, poor internet connectivity, social isolation, and general anxiety were the main concerns with online learning for students in higher education during the pandemic (UNESCO, 2020b). The slight variation between these findings and that of the current study is difference in the study scope. Contrary to the Nigerian experience, free internet data was offered to university students for online teaching and learning during this pandemic in South Africa (Ukpong, 2020).

Furthermore, an overwhelming majority of respondents to the current study valued a combination of online and face-to-face learning methods as a new normal postCOVID-19 teaching and learning strategy for pharmacy students in Nigeria. In agreement with this finding, Diploma in Pharmacy students in Malaysia also favoured a blended learning approach (Lean et al., 2020). This finding is also consistent with that of other previous studies which reported that blended learning is more preferable and suitable for training healthcare professionals (Rowe, Frantz, \& Bozalek, 2012; Duque et al., 2013; Makhdoom et al., 2013; Figueroa et al., 2020). These findings corroborated that of other studies which have shown that online teaching and learning has been growing in the form of a collaborative, rather than a substitute, teaching tool (Lorenzoni et al., 2019; Adnan \& Anwar, 2020). For effectiveness and sustainability, face-to-face contact with an instructor is necessary for online teaching and learning.

\section{Limitations}

The main limitation of the study is the use of self-reported method only which may be subject to response bias, and the use of mixed methods design is recommended to overcome this concern. The other is that the crosssectional design of the study prevents the tracking of changes in the perspectives of the respondents over time. Lastly, convenience sampling may affect the generalisation of the study findings to other nations that share similar characteristics with respect to pharmacy education.

\section{Conclusions}

There was discontinuity of learning for the majority of undergraduate pharmacy students in Nigeria during the COVID-19 school closure. Moreover, COVID-19 schools' closure impacted on the academic lives of the students. The high cost of internet data was the most commonly reported challenge with online learning. A combination of online and face-to-face learning methods was perceived as a better post-COVID-19 new normal for pharmacy education in Nigeria. Therefore, the study findings highlight the need for Nigerian pharmacy educators to learn from the opportunities presented by the pandemic to improve pharmacy education and eventually practice in the country.

\section{Acknowledgments}

The authors wish to express their profound gratitude to all pharmacy students who participated in this study.

\section{References}

Adnan, M., \& Anwar, K. (2020). Online learning amid the COVID-19 pandemic: Students' perspectives. Journal of Pedagogical Sociology and Psychology, 2(1), 45-51. https://doi. org/10.33902/JPSP.2020261309

Akpotu, N.E, \& Akpochafo W.P. (2009). An analysis of factors influencing the upsurge of private universities in Nigeria. Journal of Social Science, 18(1), 21-27. https://doi.org/10.1080/09718923. $\underline{2009.11892663}$

Amoo, A. (2019). Nigeria allocates $6.7 \%$ of 2020 budget to education Ministry. Educeleb.com. Available at: https://educeleb. com/nigerian-2020-budget-education-ministry/amp/

Anderson, C., Marriott, J.L., Carrasqueira, J., Brock, T.P., Rennie, T., Bruno, A.F., \& Bates, I. (2014). Turning the world of pharmacy education into a global community through sharing. American Journal of Pharmaceutical Education, 78(7), 130. https://doi.org/ 10.5688/ajpe787130

Azeezat, A. (2020). Coronavirus: NUC announces closure of Nigerian universities. Premium Times. Available at: https://www. premiumtimesng.com/news/headlines/382880-coronavirus-nucannounces-closure-of-nigerian-universities/

Chen, T., Peng, L., Yin, X., Rong, J., Jianjun Yang, J., \& Cong, G. (2020). Analysis of User Satisfaction with Online Education Platforms in China during the COVID-19 Pandemic. Healthcare, 8, 200, https://doi.org/10.3390/healthcare8030200

Duque, G., Demontiero, O., Whereat, S., Gunawardene, P., Leung, O., Webster, P., Sardinha, L., Boersma, D., \& Sharma, A. (2013). Evaluation of a blended learning model in geriatric medicine: $A$ successful learning experience for medical students. Australasian Journal on Ageing, 32(2), 103-109. https://doi.org/10.1111/i.1741 $\underline{-6612.2012 .00620 . x}$

Ekpenyong, A., Udoh, A., Kpokiri, E., \& Bates I. (2018). An analysis of pharmacy workforce capacity in Nigeria. Journal of Pharmaceutical Policy and Practice, 11, 20, https://doi.org/10. 1186/s40545-018-0147-9

Famodun, O. (2019). Updated list of Universities offering pharmacy programme in Nigeria. Pharmanews. Available at: https://www.pharmanewsonline.com/updated-list-of-universities -offering-pharmacy-programmes-in-nigeria/ 
Figueroa, F., Figueroa, D., Calvo-Mena, R., Narvaez, F., Medina, N., \& Prieto, J. (2020). Orthopedic surgery residents' perception of online education in their programs during the COVID-19 pandemic: should it be maintained after the crisis?, Acta Orthopaedica, 91, https://doi.org/10.1080/17453674.2020.1776461

Ige, A.M. (2014). The challenges of being a student of any public tertiary institution in Nigeria today. Journal of Studies in Education, 4(1), 128. https://doi.org/10.5296/ise.v4i1.1261

FIP [International Pharmaceutical Federation] 2020. COVID-19 Online Programmes (Webinars). Available at: https://www.fip.org/ coronavirus

Johns Hopkins Univerity. (2020). Coronavirus-19 (COVID-19) Dashboard by the Center for System Sciences and Engineering (CSSE) at Johns Hopkins University. Available at: https:// coronavirus.jhu.edu/map.html

Kandri, S-E. (2020). How COVID-19 is driving a long over-due revolution in education. World Economic Forum. Available at: https://www.weforum.org/agenda/2020/05/how-covid-19-is-spar king-a-revolution-in-higher-education/

Kossey, M.M., \& Ishengoma, J.M. (2017).Issues and Challenges of Student Financing Systems in Africa: The Case of Tanzania. International Journal of African Higher Education, 4(1), 1-13. https://doi.org/10.6017/ijahe.v4i1.10250

Lean, Q.Y., Ming, L.C., Wong, Y.Y., Neoh, C.F., Farooqu, M., Nur, S., \& Muhsain, F. (2020). Online versus classroom learning in pharmacy education: Students' preference and readiness. Pharmacy Education, 20(1), 19-27

Lorenzoni, A.A., Manzini, F., Soares, L., \& Leite, S.N. (2019). E-learning in Pharmacy Education: what do we know about it? Brazil. Journal of Pharmaceutical Sciences, 55. https://doi.org/10. $\underline{1590 / \mathrm{s} 2175-97902019000118100}$

Makhdoom, N., Khoshhal, K.I., Algaidi, S., Heissam, K., \& Zolaly, M.A. (2013). 'Blended learning' as an effective teaching and learning strategy in clinical medicine: a comparative cross-sectional university-based study. Journal of Taibah University Medical Sciences, 8(1), 12-17. https://doi.org/10.1016/i.jtumed. $\underline{2013.01 .002}$

Maxwell, W.D., Fabel, P.H., Diaz, V., Walkow, J.C., Kwiek, N.C., Kanchanaraksa, S., Wamsley, M., Chen, A., \& Bookstaver, P.B. (2018). Massive open online courses in U.S. healthcare education: Practical considerations and lessons learned from implementation. Currents in Pharmacy Teaching and Learning, 10(6), 736-743. https://doi.org/10.1016/i.cptl.2018.03.013

Nigeria Centre for Disease Control. (2020). COVID-19 Nigeria. Available at: https://covid19.ncdc.gov.ng

Okocha, S. (2020). Private universities take the lead in online learning. University World News - Africa Edititon. Available at: https://www.universityworldnews.com/post.php?story=2020061 0100106348

Okoro, R.N., \& Biambo, A.A. (2020). Pharmacy students' perceived professionalism and application of bioethical principles: Implications for teaching pharmacy ethics for patient-centered pharmacy practice. Pharmacy Education, 20(1), 158-167. https://doi.org/10.46542/pe.2020.201.158167
Okoro, R.N., Muslim, J.O. \& Biambo, A.A. (2020). Quality of life of pharmacy students in Northern Nigeria. International Journal of Pharmacy Practice, 28, 395-404. https://doi.org/10.1111/ijpp.12624

Pharmacists Council of Nigeria. (2020). Benchmark \& Minimum Academic Standard. Available at: http://www.pcn.gov.ng/files/ BMS.pdf

Pharmanews. (2016). Now that PharmD has been approved. Available at: https://www.pharmanewsonline.com/now-thatpharmd-has-been-approved/

Rowe, M., Frantz, J., \& Bozalek, V. (2012). The role of blended learning in the clinical education of healthcare students: a systematic review. Medical Teacher, 34(4), e216-e221. https://doi.org/10.3109/0142159X.2012.642831

Sorensen, T.D., Lin, A., \& Allen, D.D. (2020). Reinventing How Pharmacy Educators Connect as a Community. American Journal of Pharmaceutical Education, 84(6), Art.8151. https://doi.org/10. 5688/ajpe8151

Stone, J.K., \& Pate, A.N. (2020). The COVID-19 Pandemic across the Academy. The Impact of COVID-19 through the Eyes of a Fourth-Year Pharmacy Student. American Journal of Pharmaceutical Education, 84(6), Art. 8146. https://doi.org/10. 5688/ajpe8146

Toquero, C.M. (2020). Challenges and Opportunities for Higher Education amid the COVID-19 Pandemic: The Philippine Context. Pedagogical Research, 5(4). https://doi.org/10.29333/pr/7947

Ukpong, C. (2020). South African university set for online teaching, gives free data to students. Premium Times, April 19, 2020. Available at: https://www.premiumtimesng.com/news/topnews/388734-south-african-university-set-for-online-teaching-giv es-free-data-to-students.html

UNESCO [United Nations Educational, Scientific and Cultural Organization]. (2015). Education for all 2000-2015: achievements and challenges EFA global monitoring report, 2015. Available at: https://unescdoc.unesco.org/ark/48223/pf00002232205

UNESCO [United Nations Educational, Scientific and Cultural Organization]. (2020a). Global Monitoring of School Closures caused by COVID-19. Available at: https://en.unesco.org/covid19/ educationresponse

UNESCO [United Nations Educational, Scientific and Cultural Organization] (2020b). UNESCO UNITWIN/UNESCO Chair Holders Institutional Responses to COVID-19 Report: Preliminary results of a survey conducted in April 2020. Available at: https://apa.sdg4 education2030.org/covid19/unesco-unitwinunesco-chair-holdersinstitutional-responses-covid-19-report-preliminary-results-survey -conducted-april-2020.

Waite, L.H., Scaletta, A.L., \& Hadley, D.E. (2018). Innovative Approaches to Teaching Dyslipidemia Management in a Required Pharmacy Therapeutics Sequence. American Journal of Pharmaceutical Education, 82(7), 6317. https://doi.org/10.5688/ ajpe6317

WHO [World Health Organisation], (2020). Coronavirus disease (COVID-19) in China. Available at: https://www.who.int/china/ emergencies/coronavirus-(covid-19) 